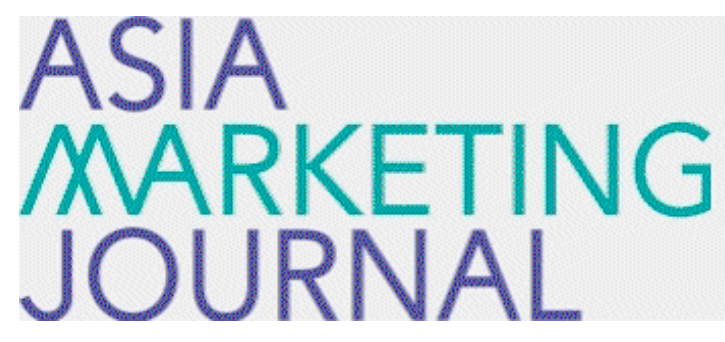

ASIA MARKETING JOURNAL

Volume 15 | Issue 4

Article 1

$1-30-2014$

\title{
Diversification Strategy through Market Creation
}

Jae Seok Jeong

Nam Jung Kim

Hyun Joo Lim

Kang

Jung Hoon Moon

Follow this and additional works at: https://amj.kma.re.kr/journal

Part of the Marketing Commons

\section{Recommended Citation}

Jeong, Jae Seok; Kim, Nam Jung; Lim, Hyun Joo; Kang; and Moon, Jung Hoon (2014) "Diversification Strategy through Market Creation," Asia Marketing Journal: Vol. 15 : Iss. 4 , Article 1.

Available at: https://doi.org/10.53728/2765-6500.1564

This Article is brought to you for free and open access by Asia Marketing Journal. It has been accepted for inclusion in Asia Marketing Journal by an authorized editor of Asia Marketing Journal. 


\title{
Diversification Strategy through Market Creation: The Case of CJ Group
}

\author{
Jaeseok Jeong* \\ Nam Jung Kim** \\ Hyunjoo Lim*** \\ Hyoung Goo Kang**** \\ Junghoon Moon*****
}

The purpose of this paper is to investigate upon a diversification strategy through market creation of CJ Group, which has contributed in positioning of the firm as one of the leading conglomerates in South Korea. With such objective, the background of CJ Group, followed by its business diversification strategies were explored, with reference to several case studies.

The history of CJ Group began with establishment of CheilJedang Industrial Corporation in 1953, as the first domestic sugar producer and exporter of South Korea. The corporation gradually expanded its business ever since at both national and global level, to include the fields of food production, pharmaceutical, biotechnology, and life chemicals. Later, CheilJedang (CJ) Group was established as an affiliate of CheilJedang Industrial Corporation. With such independence, extension of business has been witnessed across the industries of media, entertainment, finance, information technology and distribution. Thus, the current CJ Group pursues to define itself as a progressive global living culture company with four major business categories from food and food service, biotechnology, entertainment and media, and logistics.

Despite its success in today's market, CJ Group underwent hardships in its business diversification in 1990s due to indiscreet management, along with the Asian financial crisis. Here, many firms overcame the financial difficulties by taking advantage of the exchange rate for overseas expansion. Though, CJ Group tried to differentiate itself by focusing on the domestic market by creating something out of nothing. Hence, CJ Group takes a unique position among many cases of business diversification and their categorization.

\footnotetext{
* Associate Professor, Graduate School of Pan-Pacific International Studies, Kyung Hee University (profjeong@khu.ac.kr)

** Researcher, R\&BD Planning Team, KORREA YAKULT Company, Ltd. (ssgugigi@gmail.com)

*** Researcher, College of International Studies, Kyung Hee University(ixxvixii@gmail.com)

**** Assistant Professor, Department of Finance, Hanyang University(hyoungkang@hanyang.ac.kr)

***** Associate Professor, Program in Regional Information, Seoul National University(moonj@snu.ac.kr), corresponding author
} 
In an effort to identify and classify the types of growth experienced by the top 30 companies in South Korea, the firms were categorized into four groups according to their diversification strategies adapted after the Asian financial crisis. Based on the mode and time of entry, corporations were identified either as the 'Explorer', 'Invader', 'Venture Capitalist', or 'Assimilator'. Here, the majority of the firms showed the qualities of Invader, entering mature markets through large-scaled mergers and acquisitions. However, CJ Group was the only firm that was categorized as an Explorer, for its focus on the newly emerging service sector in culture-contents industry. This diversification strategy through market creation is worth examining, due to its contribution in generating simultaneous growth between the market and the company itself.

Diverse brands of CJ Group have been referred to as case studies in this regard, from 'Hatban', 'Cine de Chef', 'VIPS' to 'CJ GLS'. These four businesses, each to represent processed food, film, restaurant service, and logistics industries respectively, show CJ Group's effectiveness in creating a whole new category of goods and services that are innovative. In fact, such businesses not only contributed in advancement of consumers' wellbeing, but toward generating additional value and employment.

It is true that the diversification strategy of CJ Group requires long-term capital investment with high risk, compared to the other strategies mentioned in the paper. However, this model does create high employment and additional values that are positive to both the society and the firm itself. Therefore, the paper comes to a conclusion that the diversification strategy through market creation conveys the most positive impact relative to the others.

Key words: CJ Group, Diversification Strategy, Market Creation

\section{Introduction}

CJ Group was founded as an affiliate of CheilJedang by Chairman Lee-Byeong Cheol in 1953. Over the past several decades, CJ has experienced a significant growth and became a leading conglomerate in South Korea. CJ has been demonstrating impressive achievements in numerous fields from Food - Service, Entertainment $\cdot$ Media, New Store, Biotechnology, to
Infrastructures. As of 2009, CJ holds 54 subsidiaries including CJ E\&M, CJ O'Shopping, CJ CheilJedang Bio Pharmaceutical, and CJ Constructions.

CJ's goal is not only to succeed in meeting the numerical figures, but also to spread its culture throughout the world. Its slogan, "We Make Culture, CJ" also implements CJ's strategic efforts to develop itself as a culture-creating firm at a global level. CJ is a leading pioneer in Service Industry and its future devel- 
opments, upholding the importance of growth based on creativity.

For the past 59 years, CJ's business diversification strategy through market creation has been a major contributing factor to its developments and growth. Hence, this research aims to analyze the diversification strategy model by each type and time of entry. Furthermore, various features of the diversification model will be looked at to affirm its quality, thus to examine the model's extended impact towards the economy. Moreover, by exploring through different business areas of CJ such as Food, Food - Service, Entertainment $\cdot$ Media, and Logistics, the study will come to examine the degree of business achievement the model has initiated.

\section{History and CEO's Management Philosophy}

\subsection{The History of CJ}

History of CJ Group began with the establishment of its parent company, CheilJedang Corporation. The group was founded in 1953 as CheilJedang Industrial Corporation. Under the management by former president Lee, ByoungCheol, the group became the first domestic producer of sugar in South Korea. During the early 1950s, the level of available technology in the country was considered inefficient for sugar to be produced domestically. Regardless of the poor given conditions, CheilJedang was successful to put an end to import-dependent market. The group further became the fountainhead of domestic sugar exports after successfully shipping 200 tons of Granulated Sugar to Okinawa, Japan in 1962. The representative brand of CheilJedang, 'Baek-Seol-Pyo' was created in the same year, and the entire product line of the group was unified under the new brand name by 1972. Such achievements of the firm were well realized when the first factory in Busan was no longer capable to meet the demands for sugar. Thus, in 1970, the second industrial estate was constructed in Incheon to overcome the supply limits (CJ, 2003).

CheilJedang's expansion continued throughout the 1970s to 80s. However, the growth was not solely based on sugar production. In 1973, CheilJedang entered the feeds industry and created a new brand category, 'Poong-Nyun Feeds'. After several years of confidential research project, in 1977, CJ introduced a synthesized condiment for the first time in the domestic market. As a pioneer in the condiment industry, CJ contributed further in improving consumers' standards of living. For example, it launched a new product line for cooking oil in 1979. In the same year, CJ changed the name of the company from CheilJedang Industrial Corporation to CheilJedang Corporation and firmly took the lead in the domestic food industry. It 
soon took the lead in the food-exporting sector with achieved exports of over US $\$ 1$ billion (CJ, 2003).

From the 1980s to 1990s, CJ witnessed further expansion of its food product line to processed products such as beverages and frozen food. However, regardless of its success in the food industry, CJ invested more resources in research and development for new technology especially in terms of pharmaceutical products. In 1984, integrated institute for research was established, with up-to-date research instruments for the development of advanced technology. As a result, CJ was able to create and produce Hepacin-B, a vaccine for infections. Moreover, the firm was the third company in the world to develop Alpha-Interferon, an anti-cancer drug. Along with its considerable performances, factory for the complete pharmaceutical products was also established. Despite its domestic achievements in various fields, at the same time, CJ's focus was set further towards overseas expansion. In 1984, CJ established a joint venture 'ETI' with Arrandale in New Jersey. This served as a bridgehead for the firm to enter the market for advanced drug medicines. CJ also expanded its production in lysine, condiments, and feeds further to Indonesia, where a joint investment was carried out under the Cost Share Agreement.

From being an enterprise based on food production, CJ started to transform and grow as a company for living culture throughout the 1990s.
CJ's business diversification strategy was based on the fields of pharmaceutical, biotechnology, and life chemicals. However, with the firm's granted independence, CJ reached out to diverse markets. The dine-out restaurant 'Skylark', was an example of CJ's newly acquired food service industry in 1994. Furthermore, CJ established a joint venture with Dreamworks SKG for CJ's new entertainment business. In 1996, CheilJedang Group was officially established with its main focus on increasing revenue and growth of the firm. For the rest of the 1990s, CJ's efforts to advance its status as a leading figure in the comprehensive living culture organization led to the business extension across the industries of media, entertainment, finance, information technology and distribution.

At the turn of the century, CJ newly defined its corporate image as a forward-looking living culture company. The firm's vision and its medium along with long-term strategies were announced. One of its main strategies was to organize the company's business into four major categories including food and food service, biotechnology, entertainment and media, and logistics. Based on core competencies of brands under each category, CJ actively participated in the process of its business expansion overseas. As a global living culture enterprise, CJ endeavours to deliver healthy, enjoyable and convenient products across the world. Currently, CJ has 54 subsidiaries including CJ CheilJedang, Foodville, and Freshway for food service busi- 
ness; CJ E\&M and CGV for entertainment business; CJ O'Shopping, GLS and Oliveyoung for logistics; CJ CheilJedang Bio, CheilJedang pharmaceutical for biotechnology business; and CJ Systems and Constructions for Infrastructure industry (CJ, 2003).

\subsection{Management Philosophy of the CEO}

Founding ideology of the current CJ Group originated from the aspiration for "business patriotism, 'pursuit of rationality', and 'the most talented'. Lee, Byung Cheol, the former CEO of CJ shared a similar perception in establishing the company. Spirits for creation, ethics, perfection and being the best, along with coexistence and co-prosperity are the examples. Hence, upon these spirits, $\mathrm{CJ}$ endeavors to create healthy, enjoyable, and convenient contents for consumers as a global living culture corporation. This vision held by CJ contributed towards the firm in producing the best as well as unique goods and services. All features listed above came to create the CJ's exclusive business philosophy to become the 'Only One' in the market. The 'Only One' nature of every contents successfully led the consumers to generate maximized value out of their experience. Thus, it satisfied the mission to contribute further towards the society and the country.

Probity, Passion and Creativity are the three values CJ emphasizes the most: Probity for the basics and principles to be met; Passion for challenges and strong will to be the best; and Creativity for changes and innovative thinking. When these values come together, the synergy effect takes place in maximizing the company's growth through market creation. Lee, Jae Hyun, the current CEO of CJ Group had experienced failure in business diversification due to the financial crisis in the 1990s and indiscreet decisions. During the crisis, most firms overcame the difficulties by taking advantage of the exchange rate as a chance for overseas expansion. However, CJ chose to face the challenges through taking a different path, and endeavored to create something out of nothing. Moreover, with manufacturing industry on the downturn, CJ predicted South Korea's economic growth and employment to be generated by the future service industry.

\section{Analysis of Business Diversification Strategy through Market Creation}

For a valid analysis in categorizing the cases of business diversification, 'Mode of Entry' and 'Time of Entry' were used for classification. This approach has been widely adopted in the area of marketing and management to categorize different diversification strategies used by a firm upon its enterance into a new market (Harzing, 2002; Anderson and Zeithaml, 1984). 
To classify business diversification according to the mode of entry, Harzing's study (2010) was referred to. According to the study, there are three modes of entry; Greenfield, joint venture and M\&A. Here, firms can be classified based on whether it has created something out of nothing through a direct investment, or has carried out a joint investment or mergers and acquisition for reduced risk and secured technology.

For the time of entry, Anderson and Zeithaml (1984) suggested growth model according to different stages from introduction, growth, to maturity based on industry life cycle. Based on this model, sample of 30 firms were classified into two groups. One group consisted of the firms that entered a market that had already been matured to avoid risk, and another with firms that entered at the introductory stage to create a new industry.

This study classified the types of growth experienced by the top 30 corporations in South Korea. The corporations were classified into four different types based on their diversification strategies adapted after the Asian financial crisis. Each category was grouped upon the mode of entry and the time of entry. Based on such, the four subsets of companies were identified with combinations of high and low levels of accumulation and growth-value styles: Explorer, Invader, Venture capitalist and Assimilator, each showing unrelated diversification practices (Kang et al., 2013). Explorers are the companies with high accumulation and high growth-value styles. Venture capitalists show low accumulation and high growth-value styles; and Invaders with high accumulation and low growth-value styles. Assimilators represent low accumulation and low growth-value styles.

The Venture Capitalists, like Kolon and OCI, generally induce growth by acquiring small-sized firms in the introductory stages of an industry. The firms that are subjected for the acquisitions are usually pioneers with core technologies at possession. On the other hand, the Invaders attempt to enter the market in a more stable manner. Thereby large-scaled mergers and acquisitions are carried out as a way into the already matured industry. Corporations such as Lotte, SK, Hyundai Heavy Industries, Kumho Asiana Group, LG, and Hanjin fall into this category. On the other hand, Hyosung, Samsung, KT, Shinsegae, and Dongbu are classified as the Assimilators. Assimilators tend to enter a matured market through vertical integration, thus securing the required know-hows and competencies. However, CJ falls under a rather unique category when reflected upon its history [See Figure 1]. In Figure 1, the accumulation style increases with the diversification through greenfield investments or through the build-up of resources and capabilities, while the accumulation style decreases as firms diversify by acquiring or allying with existing firms or factors. According to the core argument of the resource-based view of the firm with respect 
〈Figure 1〉 The Accumulation \& Growth-Value Styles Matrix: The CJ Explorer (Kang et al., 2013)

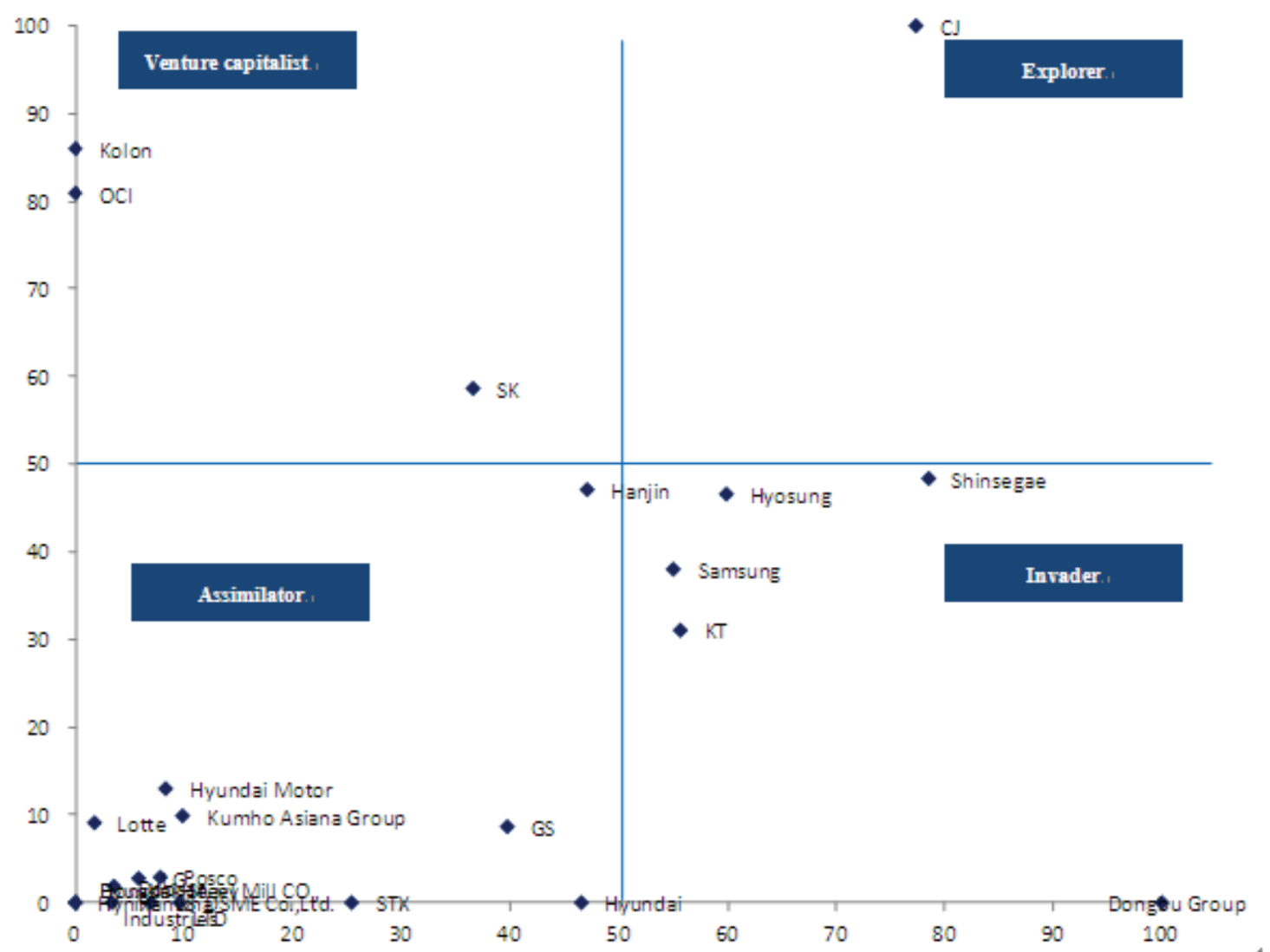

Horizontal-axis (accumulation style) $=$ (the revenue from diversification by accumulation)/(the revenue from diversification by both accumulation and acquisition): Vertical-axis (value style) $=$ (the revenue from diversification into growth sectors) /(the revenue from diversification into both value and growth sectors).

to how a firm's resources are developed, M\&A transactions can be regarded as low with respect to accumulation style in the diversification framework. By contrast, greenfield investments can be regarded as expanding the bundle of resources that a firm accumulates until its time of market entry (Wernerfelt, 1984).

Regarding the growth-value style, it can be defined as the extent to which firms diversify in the growth sector rather than in the value sector. Business groups that diversify more in growth sectors receive high growth-value style scores; whereas business groups that diversify more in value sectors receive lower growth-value style scores. When a company enters a sector at its founding or during the growth stage of its life cycle, the company engages in the growthstyle. However, if other companies enter the 
same sector during their maturity or saturation stage, the entering companies are regarded as undertaking value-style diversification. To classify the growth-value style of a company's diversification, it has been observed how many significant players, including a company's subsidiaries or other large firms, exist in a sector at the moment of entrance. By developing a new market into an industry, thereby encouraging an accompanied growth between the firms and the market, only CJ fits in the category of Explorer.

In the present time, firms that are of Venture Capitalists and Invaders tend to have their focus on manufacturing, and Assimilators on distribution, which all belong to the matured service sectors. However, Explorers focus on the newly emerging service sector introduced after 2000, especially through culture-contents industry. However, majority of the top 30 corporations in South Korea have shown the qualities of Invaders, entering mature markets through large-scaled mergers and acquisitions (Kang et al., 2013).

CJ's growth model upon business diversification strategy has been proven successful through its product, service and industry development. As a result, CJ was able to bring simultaneous growth between the market and the company itself. These characteristics of CJ are unique compared to other Korean corporations. They are also worth to be observed in comparison with the other multinationals' diversification strategies such as Virgin and Apple of the
United States. The Virgin group started as a small mail-ordered record-selling company, which also turned to business diversification strategy to expand the market as well as the company itself from Virgin Mobile to Virgin Galactic. The similar story goes with Apple, which began in 1970 as Apple I. Later, it created a whole new industry and market through its products such as iPhone, iPad, and Apple TV. The growth strategy shared by these firms gave way for the firms to become multinationals with enormous power for value creation. In the case of Virgin, it has created over 50,000 job opportunities internationally with sales over 20 trillion Korean won. Apple has also introduced a new product area of Smartphones, achieving average annual growth rate of 61 percent over the past five years.

\section{Case Studies for Successful Business Diversification Strategy through Market Creation}

\subsection{HatBan - The First Preserved Rice of High Quality in Korea}

CJ CheilJedang decisively entered an unexplored market, where it was successful to bring positive responses from consumers for strategic marketing plans and constant R\&D efforts. 
'HatBan' contributed in eliminating the negative stereotypes previously existed for preserved rice, and became an innovative product for changing dietary life pattern.

Dietary life had been changing with continuous evolutions in social lifestyles, such as increased number of female employment and single family. CJ has witnessed the importance in such changes - the need for products that are easy to use and consume. To satisfy more cosmopolitan consumers, instant food and retortable pouches were introduced, including cereal and ramen.

Countries consuming rice as the staple food such as Japan and other Asian countries also introduced preserved rice. Numerous Korean companies introduced similar products as well. Dongwon and Cheon-il lauched frozen rice; Birak and Sambon Food introduced retort rice with dried and frozen soup in 1994. However, these products failed to satisfy the consumers' expected quality and taste. Thus, the market's interest moved towards the aseptic packaged rice, which has improved the taste by remedying the shortcomings of retort rice.

Production of aseptic packaged rice required more capital investment compared to that of retort production. In order to optimize the quality of the product, advanced capital investment and management skills were necessary for the pre-treatment, disinfection, and cooking process (Hur et al., 1999). Japanese firms were the first to possess such technique in production, and its preserved rice market showed 14 percent of annual growth (Kim \& Park, 2001). CJ took this as an opportunity to import the aseptic packaged rice produced by Shinwa Kikai Co. Ltd and entered the Korean market.

CJ saw the future potential of aseptic packaged rice through importation. Upon this observation, CJ was able to make a bold decision to invest for the production of aseptic packaged rice. As a result, the first aseptic packaged rice, 'HatBan' was produced in 1997, which was highly advanced in quality compared to the frozen or retort rice products. CJ applied the clean room system for hygiene and safety of the product, as well as high-pressured aseptic packaging process for freshness of the product during the distribution. R\&D effort has also been consistent to improve the product quality further.

\section{〈Figure 2〉 CJ Cheilledang HatBan}

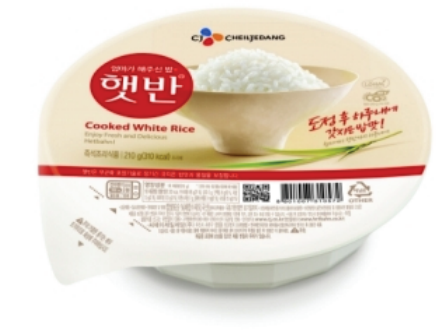

\subsubsection{HatBan’s Marketing Strategy}

CJ successfully altered the consumers' negative perception of the preserved rice as unhealthy and low quality to be more positive. 
Furthermore, to introduce a whole new product category of 'aseptic packaged rice' to consumers, CJ has successfully brought out an effective marketing plan.

The whole new brand 'HatBan' was created to deliver the message as being 'HatBan = Delicious' to consumers. The product package was also designed in accordance with the message. Through further advertisements, HatBan also attracted consumers by suggesting various ways of possible usage according to different TPO (Time, Place and Occasion). Based on high quality and brand power, CJ made large distribution efforts. CJ held try out events at wholesale discount stores where retailers were asked to display the product on the most noticeable spot. Such efforts contributed in removing the psychological barrier and consistent inducement of product tryouts among consumers. Hence the preserved rice market, triggered by the introduction of HatBan, grew up to 150 billion Korean won. CJ now holds the most dominant position in the market (CJ, 2012).

\subsection{CJ Entertainment - Cine de Chef}

"CGV has risen to be a cinema of a global scale with unique, state-of-art technology. If you would like to see how the future will be, you have to see what CGV is and has been doing in South Korea."-Jeffrey Katzenberg, CEO of Dreamworks SKG
CJ is a company that has cultivated the growth of Korean film industry. It has introduced a multiplex cinema during a recession and popularized the film culture. CJ has also raised the quality of movie contents with constant investment in production through CJ Venture Investment. In 2000, the company successfully brought a vertical integration between cinemas, producers and distributors (CJ, 2003).

However, a growing competition among firms and declining industry growth profitability in the domestic film industry led to deterioration of the Group. Moreover, Showbox had taken the top of the distribution rank in 2005, which made $\mathrm{CJ}$ realize the crisis it was faced with. In order to escape from the downfall, CJ introduced various premium services differentiated from the previous multiplexes. 'Sweet Box', 'Gold Class', and 'IMAX' are the examples of specialized cinemas that provide premium film service, and 'Cine de Chef' also falls under the same category (CJ, 2012).

Cine de Chef - 'A cinema with a chef' stands out to be a cultural space where a premium cinema is combined with a restaurant service. The service has been launched as 'a premium cinema for the top 1 percent', through which CJ Entertainment wanted to take a step further in service differing from any other ordinary 'private cinema'. Customers of Cine de Chef can enjoy gourmet meals before the movie starts. The chefs are renowned with credentials of having worked in famous hotels and 
restaurants, or graduated from 'Le Cordon Blue', a famous French cookery school. After the meal, consumers are offered with specially designed seats with the most comfortable atmosphere to watch the film. The cinema at Cine de Chef, possessing the most up-to-date screens and sound systems technology, was designed to maximize the consumer experience.

Cine de Chef started in May 2007 in Apgujeong CGV (as known as the Seoul store) with one hall with 30 seats. With the Seoul store as the yardstick for pricing, a ticket costs 40,000 won being the highest among the existing specialist cinemas of CGV. This cost excludes the meal price, where lunch is maximum of 46,000 won and dinner at 110,000 won. Therefore, when consumers are to enjoy both services, they have to pay the price that is 15 times higher than of ordinary cinemas. Regardless of the high cost, it has set the record of cumulative audience number of 2,000 for a few months following the launch (Yonhap News Agency, 2007). Moreover, Cine de Chef has experienced steady increase in sales from 830 million won

〈Figure 3〉 Meals at Cine de Chef (Source: CGV Website)

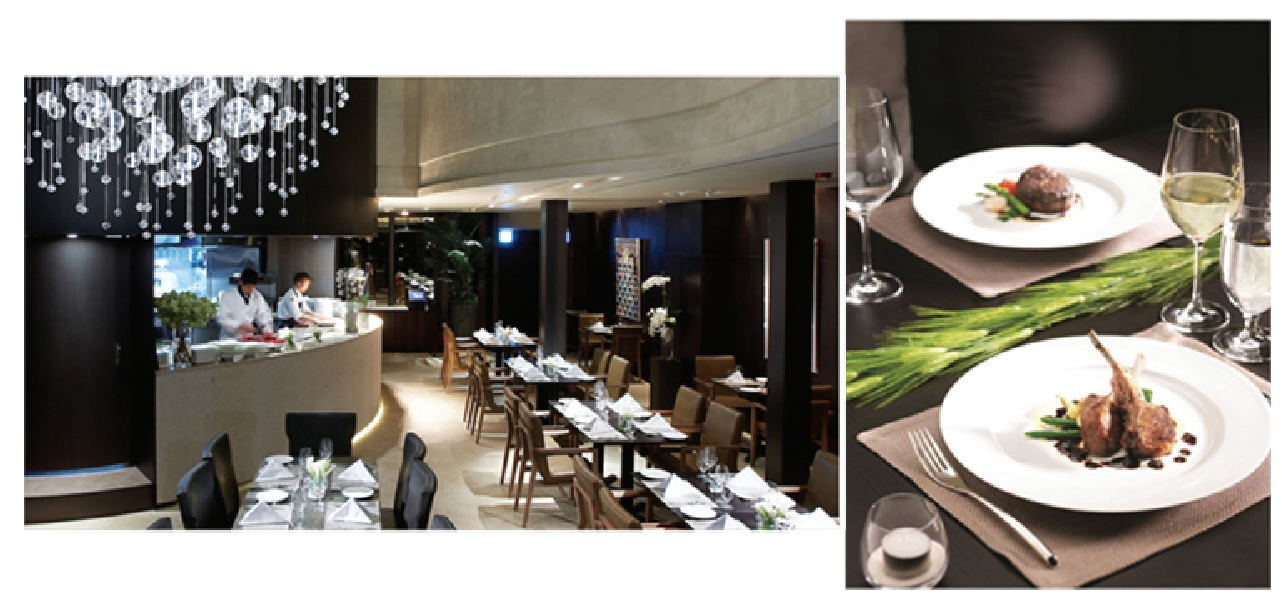

〈Figure 4〉 Interior of Cine de Chef Cinema (Source: CGV Website)
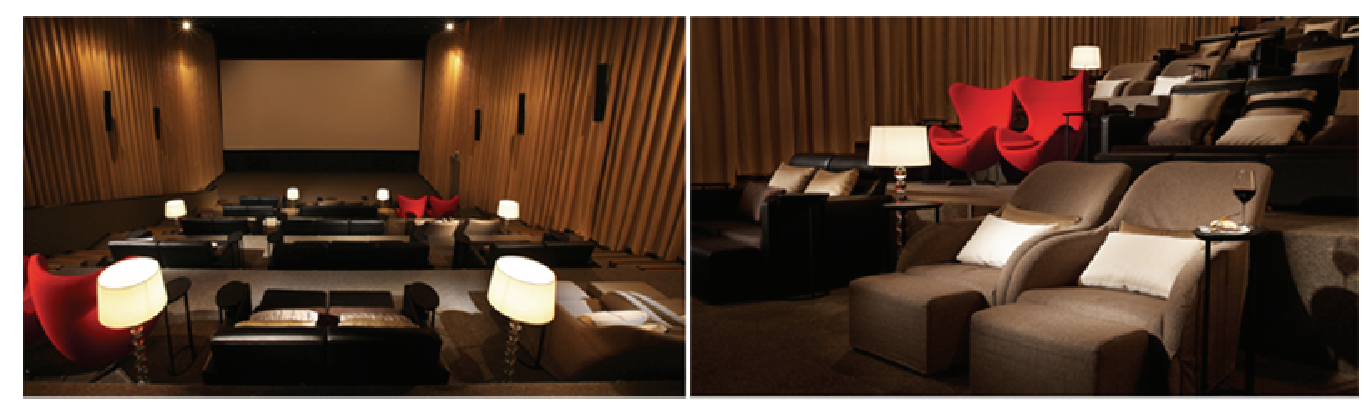

Diversification Strategy through Market Creation: The Case of CJ Group 11 
in 2007 to 2.69 billion won in 2011. Simultaneously, the operating profit was converted into profit for the first time in 5 years. The Seoul store was renewed in 2010, to have 2 halls, each placed with 30 and 48 seats. Cine de Chef Centum City store (also known as the Busan store) was launched in March 2009 with 2 halls providing 30 and 63 seats each, as well as steady sales increase (CJ, 2012).

\subsubsection{Marketing Strategy of Cine de Chef}

The achievements mentioned had been possible only through CJ's differentiated marketing strategy. Unlike other ordinary cinemas, Cine de Chef has focused on targeting business consumers rather than individual consumers. CJ viewed the service of Cine de Chef more suitable for businesses in offering services to treat their premium customers. Hence, Cine de Chef started rental services for business customers to use the cinema as a venue to hold important events for VIPs. Famous financials, renowned luxury brands, and pharmaceutical companies were some of the customers, who aimed to increase their customers' loyalty by providing them special services like that of Cine de Chef.

The current slogan of Cine de Chef, "For your very special moment", intends to appeal to higher variety of mass while maintaining their premium brand image. The result given by this effort led to an increase in the number of individual customers by 56 percent of the overall sales, compared to high number of rental customers at the beginning of the launch. For higher-income customer groups, Cine de Chef is frequently used as a place to make a proposal or to celebrate anniversaries. Recently, the number of family customers also has been increasing. Similar trend can be seen at the Busan store-like the introductory stage of Seoul store-where rental customers account for 77 percent of the total sales. However, CJ plans to gradually expand the number of individual customers.

Despite its success at the very early stage, Cine de Chef has not stopped making efforts to reach higher goals in the future. For example, China is one of the largest potential markets viewed by Cine de Chef. It may be difficult for any firms to enter the Chinese market with short accumulated information and the absence of network system required for provision of services. However, CJ has already entered China with CGV multiplexes, which suggests demands for differentiated services like that of Cine de Chef. With its previous experience in China, CJ Entertainment has been analyzing possible potential customer groups of its brand, and thus has firm understanding of Chinese customers. Based on the analysis, Cine de Chef's new location and menus would be developed, beginning its new journey in the global market. 


\subsection{VIPS - The First Korean Native Family Restaurant}

The success of VIPS is another significant example of CJ's diversification strategy through market creation. CJ Foodville started in 1994 as CJ CheilJedang's food service division. CJ at the time made a decision to expand its business through diversification methods, setting its way towards specialization in food services.

In 1990s, steady economic growth and increase in women employment led to changes in consumer lifestyles, which resulted in rising number of dine-out customers. However, CJ lacked in experience with food service sector. The company wanted to adopt an advanced system to obtain required skill and information about the market. The system included the overall process of food supply and distribution, menu development, and store management. Thus, the food service division concluded a technical assistance agreement with Japan's signature restaurant 'Skylark', and brought the brand into the domestic market.

The three major know-hows CJ CheilJedang acquired from the advanced system demonstrated by Skylark were the central kitchen system, food logistics system, and product development skills. Central kitchen system refers to the centralized food distribution concept, through which semi-cooked ingredients are consistently supplied. This allows for a balanced distribution of ingredients with possible cost reduction.
Even though the system was effective for operating of 30 or more stores, CJ adopted the Central Kitchen system in the introductory stage as an investment for the future and for a complete acquisition of knowledge.

It is also very crucial for the food to stay fresh during distribution. Therefore, to keep and manage the freshness of ingredients, CJ has adopted the cold chain system to dramatically improve the quality of management skills.

Moreover, Skylark had its strength in merchandise planning through developing a menu that suited the taste of domestic consumers. This very strategy was used by Skylark at its early entry stage in the Korean market, leading to an effort to find the right menu for Korean consumers.

The achievements of such organizational learning vary differently according to the company's absorptive capacity. The successful case of VIPS proved the satisfactory results of organizational learning from Skylark.

CJ did not simply just bring foreign family restaurants into domestic market, but has created its own brand "VIPS" to enter the food service industry. In comparison to low and mid-priced image of Skylark, VIPS brought an image as a fancy, high quality restaurant. Despite the success shown by increased average customer transaction from 7,000 won to 15,000 won, VIPS claimed to offer 100 percent chilled meat like that of the other high quality steakhouses (CJ, 2012). 
The flavor that came from the differentiated food ingredients originated from the central kitchen system and cold chain system. Moreover, VIPS went further to offer 40 to 90 different types of buffet like salad bar as its main item, and continued the efforts to find the right steak sauce suiting Korean consumers' taste.

However, along with its entry to the market, VIPS could not avoid the fierce competition with existing foreign family restaurants like TGIF, Bennigans, Tony Roma's, and Sizzler. Moreover, the Outback Steakhouse, which entered the Korean market in 1999, had been expanding its stores by more than 10 annually and had been aggressively taking up the market share.

In order to cope with the threats, VIPS introduced a salad bar as their specialized item along with customer-oriented services. In fact, VIPS was not the first to introduce the salad bar. Sizzler already had been offering the salad bar to cut down on personnel expenses. However, the system went quite different for VIPS, where it offered various choices from mixed salad, chef grill, seafood, bakery, fruits, to dessert. This has allowed the customers to be in control of choosing what they would like to consume at whichever amount they want. Along with the 'wellbeing' trend, VIPS' salad bar gained huge popularity among consumers and went further to take 50 percent of total sales to ensure VIPS' success.

\subsubsection{Marketing Strategy of VIPS}

The name VIPS stands for, "Very Important Person's Society”. This is to express the brand as a food service that puts customers' wellbeing as the top priority. VIPS' effort to match its name first starts with various menu offerings at the salad bar, which has expanded its customer range beyond that of the 20s and 30s. Furthermore, VIPS shows constant effort

〈Figure 5〉 VIPS's Salad Bar (Source: CJ Website: http://english.cj.net)

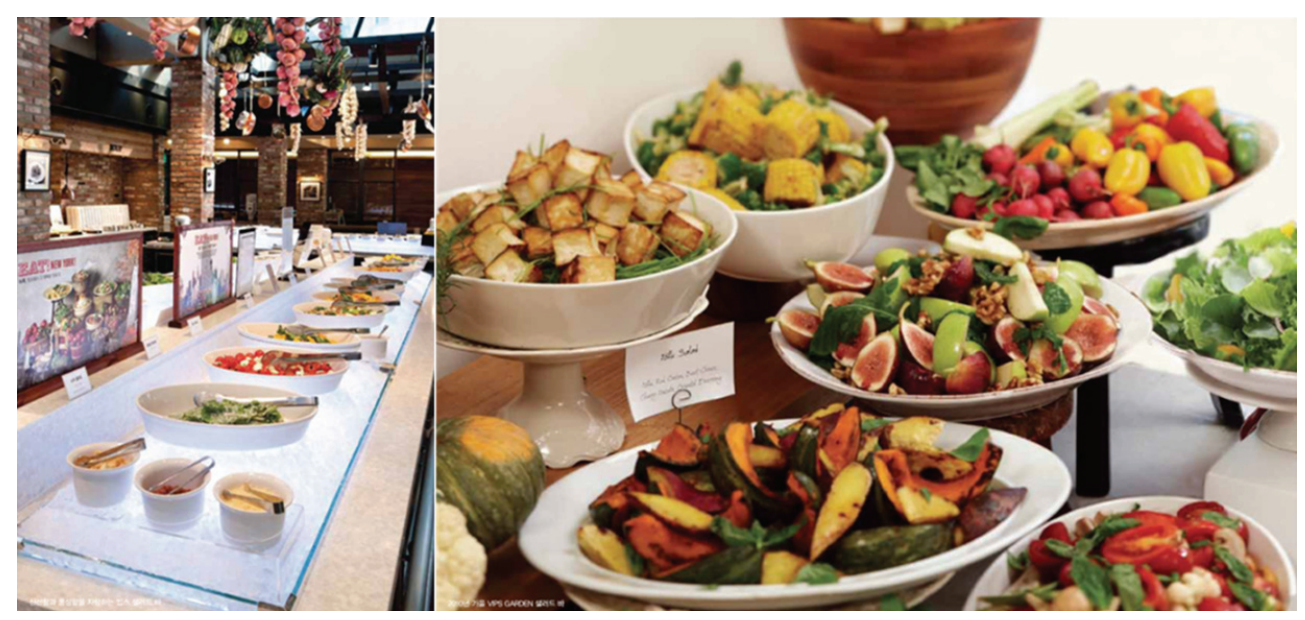

14 ASIA MARKETING JOURNAL Vol. 15 No. 04 January 2014 
for menu development to suit customers' tastes, and tries to actively communicate with customers through selecting evaluation panels among them for new menus.

Their careful consideration for customers is also shown through the way they treat customers from the time of entrance to their exit. Before they enter the store, customers are offered with couches and refreshments while waiting. They are assigned with certain servers in charge, who helps the customer with ordering and billing on the spot.

Such various endeavors of VIPS led to 38.2 percent market share growth in 2007 from 10.4 percent in 2001. Hence, VIPS could finally overtake the Outback Steakhouse (37 percent market share in 2007) in market leadership. The enormous rate of 330 billion Korean won with 76 stores was attributed to the lead in 2011 (CJ, 2012).

CJ's diversification strategy through market creation has also been proven through VIPS of CJ Foodville. The know-how gained from Skylark has led to the creation of steak with salad bar. Moreover, the diversification model through market creation has led VIPS to consumeroriented thoughts that have brought successful development of its core competencies.

\subsection{PL - The First Distribution Service in Korea}

CJ GLS tried to enter the logistics sector with the third party logistics service. CJ GLS was a late mover in the sector, but has overcome this weakness with its superior market diversification strategy. As a result, CJ GLS was able to successfully attain and maintain its dominant position in the market.

In 1990s, CJ entered the market relatively later (Kim et al., 2008) that others, when Korean logistics market had already been classified as Red Ocean with high competition. At that time, the competitions among firms were intense over acquiring a bigger piece of the market share, which led to a decrease in profitability.

To overcome the situation, CJ GLS introduced a business model called the "third party logistics', rather than extorting the competitor's market share. As figure 1 shows, the third party logistics refers to outsourcing the entire logistics activities to the third party to reduce the cost involved, except for product manufacturing (Hertz \& Alfredsson, 2003). This service differentiates itself from ordinary logistics service, as it provides integrated multiple logistics functions ranging from supply of raw materials, production, and distribution of products. With this third party logistic system, CJ GLS could attract both businesses that possessed its own logistics system but wanted third party assistance, and the infant firms that did not hold any independent logistics system for B2B purpose.

By introducing a whole new business model 
〈Figure 6〉 3PL of CJ GLS (Source: Kim, 2006)

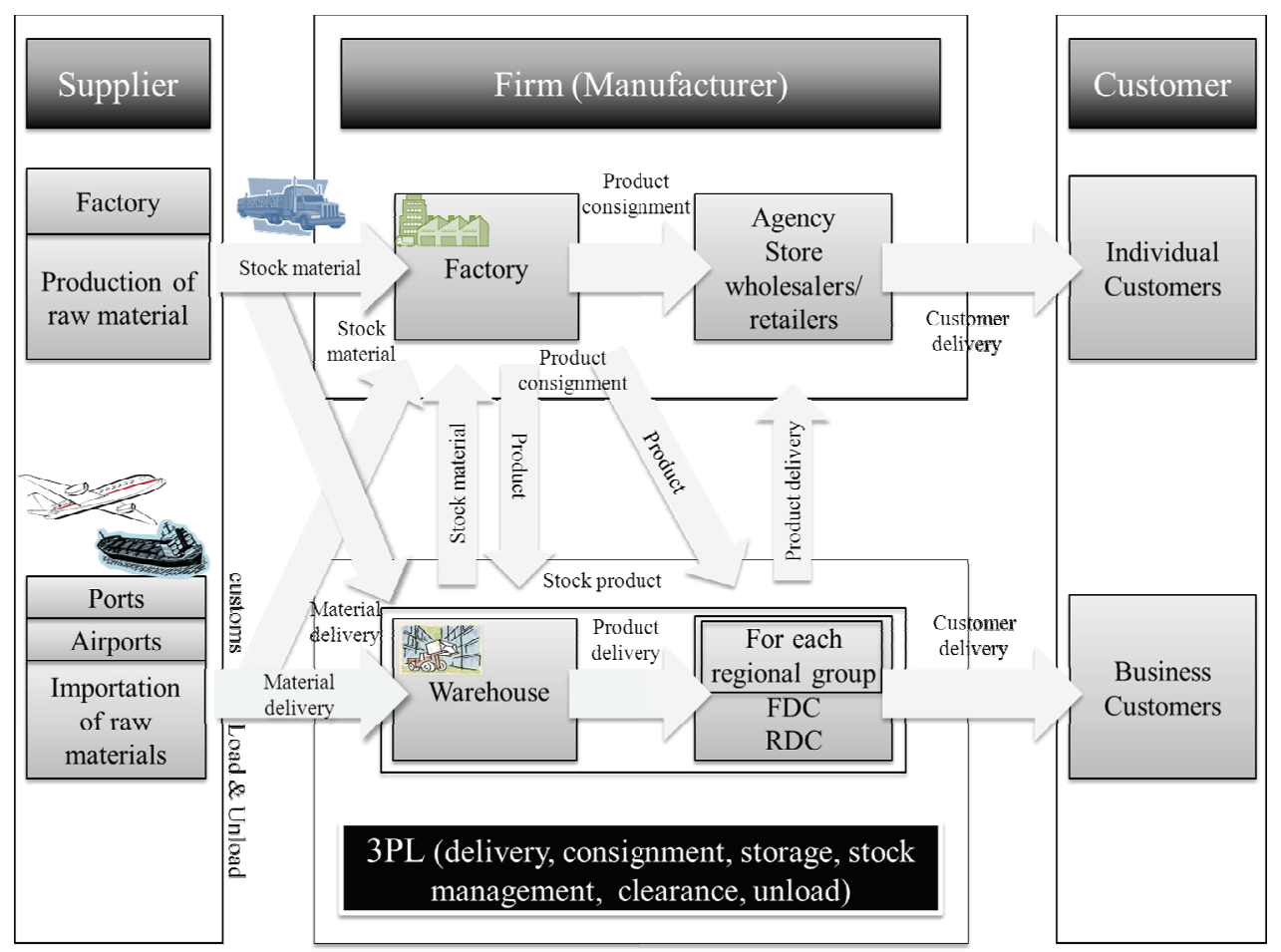

to an existing market, CJ GLS managed to overcome the disadvantageous position including the number of vehicles and warehouses. In 2004, it was ranked first in third party logistics market, and fourth in ordinary logistics. Its sales also experienced 28 percent annual growth from 63.7 billion won in 1998 to 380 billion won in 2004 (CJ, 2012).

\subsubsection{Core Competence of CJ GLS: RFLF/USN Based Logistics Information System}

CJ GLS focused on Logistics Information System to gain advantage over its competing logistics companies (Kim, 2006). First, unlike the other companies who applied the foreign logistics information system solutions, CJ GLS minimized the difficulties in using the system by developing its own in-house system to suit the domestic environment and the firm's capability.

Moreover, as shown in figure 2, by creating RFLR/USN based logistics information system, it managed to increase efficiency and call for new demands (Cho, 2009). The previous method barcodes had low cognitive faculty and often caused delays in order managements and transportation management processes. It also led to inaccurate stock management. Hence, CJ GLS 
adopted the RFID based logistics information system, which uses standardized RFID tag to trace the whole process of product manufacturing to final distribution in real time. It also automated the information collection in the logistics process. Furthermore, by introducing the RFID based third party logistics system, CJ GLS could provide differentiated service, such as the Real Time Locating System, Cold Chain System, and Secret Mark services.

With excess supply in the current domestic logistics market, CJ GLS made a move to target the global logistics market. The global demand for third party logistics is expected to increase due to the expansion of multinational and domestic firms' international sales. Hence
AHF, a global logistics corporation from Singapore was merged by CJ to expand its branches as CJ GLS Asia, CJ GLS America in 2007, and CJ GLS Central America in 2008. Through its branches, CJ GLS attracted local customers, and through a network between the domestic production line and local production line, it could provid logistics services in a global scale.

\section{Conclusion}

Companies stimulate positive externalities on society through employment and additional value creation (Kang et al., 2013; Jeong et al.

〈Figure 7〉 RFID based logistics information system of CJ GLS (Source: Cho, 2009)

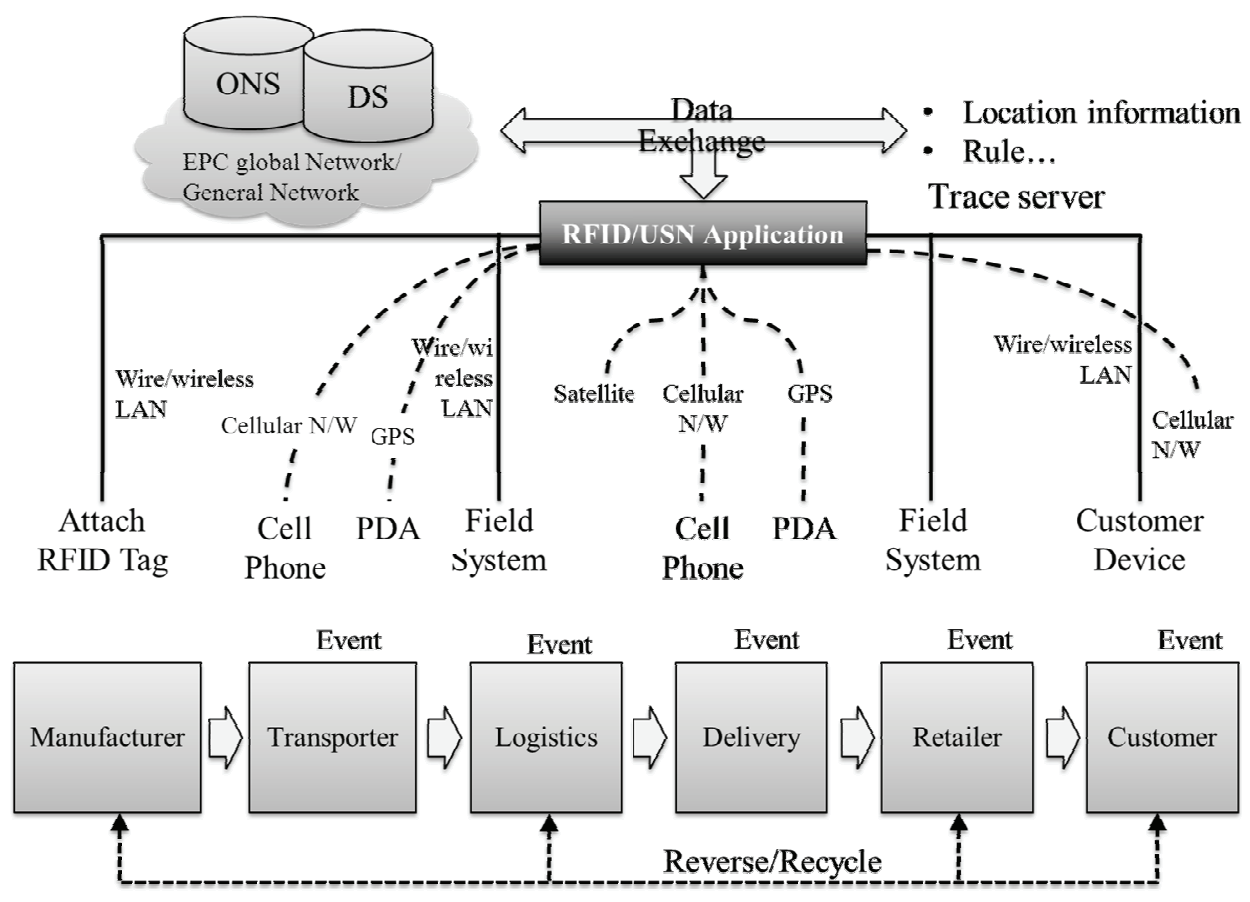


2013). With these as an index for analysis, CJ's diversification strategy through market creation widely differs from other firms classified as Venture Capitalists, Invaders or Assimilators. In fact, the study shows that the strategy used by CJ is more likely to generate greater additional value and extra units of employment.

This is because the majority of sectors that CJ has tried to challenge were of the service industry, including food, culture contents and online services. The service industry usually requires knowledge-intensive labor, which may have caused considerable impact on generating additional value and employment. In fact, CJ Foodville was ranked at the top for the highest employment rate from 2003 to 2008 (The Korea Chamber of Commerce and Industry, 2010).

In contrast, most of the other conglomerates tended to enter manufacturing industry through the Invader diversification strategy, despite the fact that employment creation in manufacturing sector has been constantly decreasing since the mid-1990s. Export manufacturing sector especially showed sharp fall in the average employment rate of 15 percent in 2000 to 8.2 percent in 2009 (The Korea Chamber of Commerce and Industry, 2010).

Note that Bank of Korea has set out the definition of production inducement coefficient, value addition coefficient, and employment inducement coefficient. The production inducement coefficient refers to the outturn unit that is given directly or indirectly from each industry sector to meet an increase of an additional unit (10 billion) of the final demand set by the Bank of Korea. Likewise, the value addition coefficient refers to the amount of value caused directly and indirectly by each industry to meet an increase in final demand. In the same manner, the employment inducement coefficient indicates the unit of employment directly or indirectly created from each industry sector due to a one-unit increase in final demands (The Korea Chamber of Commerce and Industry, 2010).

Accordingly, Hatban - the first brand to introduce the produce line of aseptic preserved rice into Korea-has generated 340 billion won and more than 1,800 employment opportunities in 2010 (CJ, 2012). This has resulted from using domestically produced rice for its production, contributing to the profitability of domestic farmers. Hatban also fosters the packaging industry through its related packaging processes. In short, introducing Hatban to the market has contributed front-to-back for the growth of various industries.

VIPS, the native Korean family Restaurant, has survived through the competition with foreign family restaurants and now takes the leading position in the market. This success was due to differentiation of menus and customer-oriented services it offered. The production rate generated by the growth of VIPS in 2010 reached 1.8 trillion won with 13,000 employment opportunities (CJ Group, 2013).

CJ CGV has also introduced a multiplex cin- 
ema into domestic market for the first time, and CJ has been working constantly to provide distinguished services such as Cine de Chef. Moreover, CJ CGV has led the growth of Korean film industry, which created 2.5 trillion won of production value and 57,000 employments during the progression (CJ Group, 2013).

As mentioned above, business diversification strategy through market creation requires longterm capital investment with high risk. Hence, only few firms apply the strategy to their own management model. However, the model does create high employment and additional values that are positive to the society and the country. Thus, it carries the most positive impact among all four models of diversification.

〈Received August 5. 2013〉 〈1st Revised October 1. 2013〉 〈2nd Revised October 8. 2013〉 〈Accepted October 11. 2013〉

\section{References}

Anderson, C. R. and Carl. P. Zeithaml (1984). "Stage of the Product Life Cycle, Business Strategy, and Business Performance," The Academy of Management Journal, 27(1), 5-24.

Cho, S. J. (2009). "CJ GLS Case: "RFID/USN based Electronic Logistics Information System," RFID/USN LIVE 2009 Conference.
CJ (2003), “CJ 50 years: 1953 2003,” Seoul: CJ.

CJ (2012), Unpublished Internal Report, Seoul: CJ.

CJ Group (2013), “CJ Group,” (accessed on July 31, 2013)

Harzing, A.W., 2002. Acquisitions versus greenfield investments: International strategy and management of entry modes. Strategic Management Journal, 23(3), 211-227.

Hertz, S and M. Alfredsson (2003). "Strategic development of third party logistics providers," Industrial marketing management, 32(2), 139-149.

Hur, S. H., M. H. Shin, and J. H. Hong (1998). “Microbiological Quality Control of Cooked Rice by Aseptic Process Using Heat Shock Treatment," Journal of Food Science and Nutrition, 27(6), 1094-1099.

Jeong, J., H. Jeong, K. Ko, J. Moon, and H.G. Kang (2013), "Success Factors of Paris Baguette's Bakery Franchise Business: Industry Competition and Core Competence Analysis," Asia Marketing Journal, 15(2), $1-27$.

Kang, H. G, J. Moon, and J. Jeong (2013). "How to undertake apparently unrelated diversification and build an empire well?," Actual Problems of Economics, 143(5), 275-286..

Karnani, A. G. (2010). "Five Ways to Grow the Market and Create Value," Clariden Global Insights, 1(1), 5-20. 
Kim, D. H and H. S. Park (2001). "New Product Strategy as a Response to Changing Customer Lifestyle ; The Case of CJ Haetban," Journal of Consumer Studies, 12(3), 191-208.

Kim, C., K. H Yang, and J. Kim (2008). “A strategy for third-party logistics systems: A case analysis using the blue ocean strategy," Omega, 36(4), 522-534.

Kim, C. (2006). "Case: From e-Business to Ubiquitous Informatization: CJ GLS Ubi- quitous Logistics Information System," The Korea Society of Management information Systems Conference, Seoul.

The Korea Chamber of Commerce and Industry (2010), Unpublished Report, Seoul.

Wernerfelt, B. (1984). "A resource based view of the firm," Strategic Management Journal, 5(2), 171-180.

Yonhap News Agency (2007), "Luxury cinema gains popularity among high-income moviegoers", (accessed on October 1, 2013) 
〈Appendix 1〉 Company Overview (Source: http://english.cj.net)

\section{CJ creates a Healthy, Happy and Convenient Lifestyle}

sis propelling itself as a global leader.

Our relentless efforts in strengthening our key businesses in Food \& Food Service. Bio Pharma, Entertainment Media and Home Shopping \& Logistics have enabled us to grow into a global company with world-class competitiveness

\section{$\mathrm{C} J$ is in our life providing us health, enjoyment and convenience.}

$C J$ has been recognized as an ever-changing company leaping forward creating new imagery and as a trustworthy company always there providing you with health.

enjoyment and convenience.

CJ creates an enjoyable lifestyle.

CJ will be always be there as a trustworthy corporate citizen, a global company loved around the world, and as a comprehensive company revolved around life and culture which enriches people's lives and brings more happiness.

\section{Compan}


〈Appendix 2〉 Company Mission \& Vision (Source: http://english.cj.net)

\section{CJ makes your life \\ More Healthier and More Enjoyable}

\section{The CJVision}

To Become a Global Enterprise that Creates a

Healthy, Happyand Convenient Lifestyle

\section{The CJMission}

To Create Premium Value for Customers.

Shareholders and Employees by Supplying the Best

Products and Services through the "Only One" Spirit

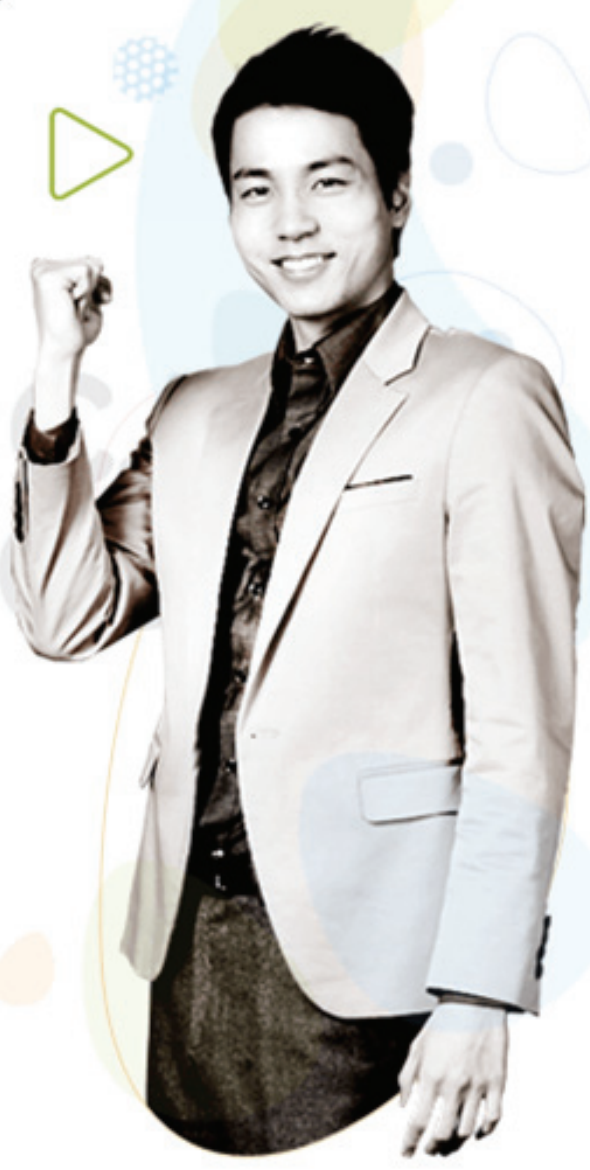


〈Appendix 3〉 Organization Structure (Source: IR data from http://english.cj.net)

\section{Group Overview - Shareholder Structure}

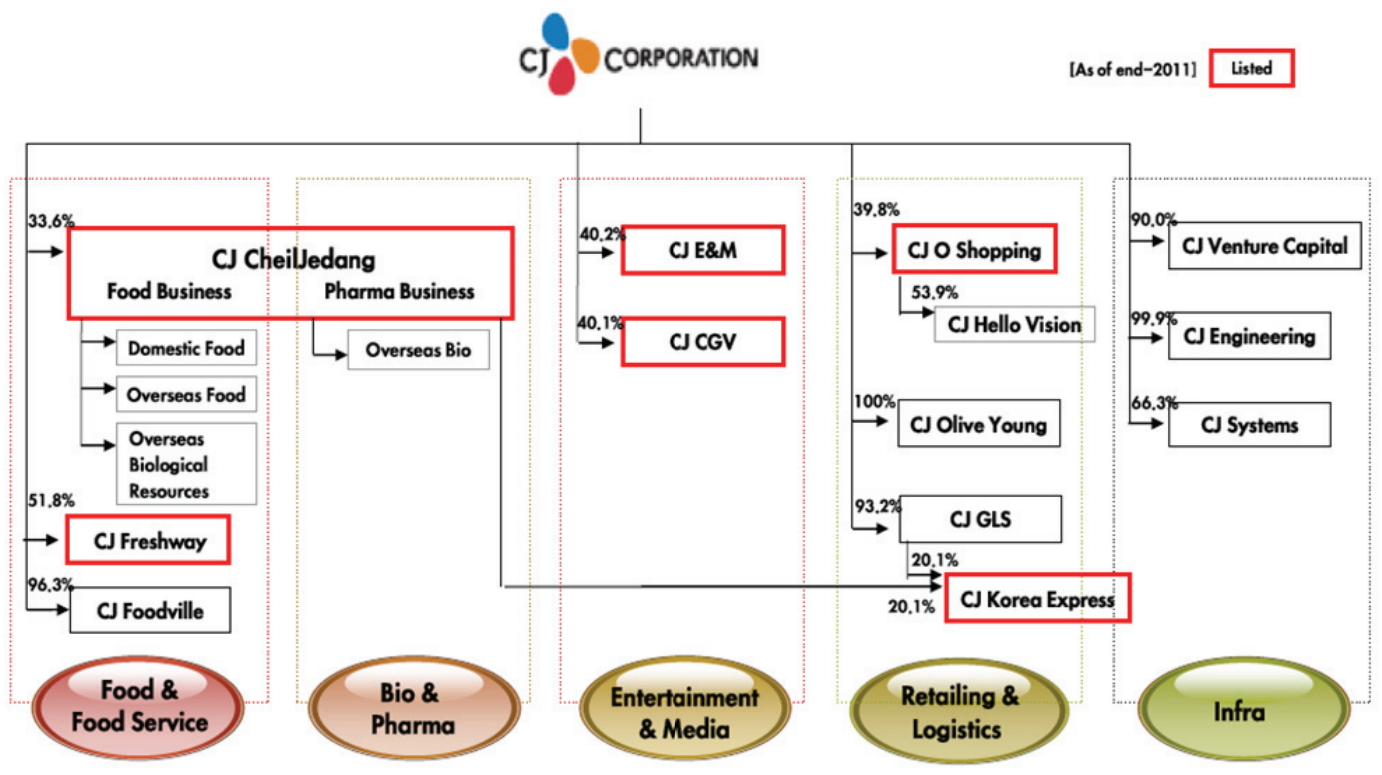




\section{Enhancing efficiency and synergy through transparent corporate governance}

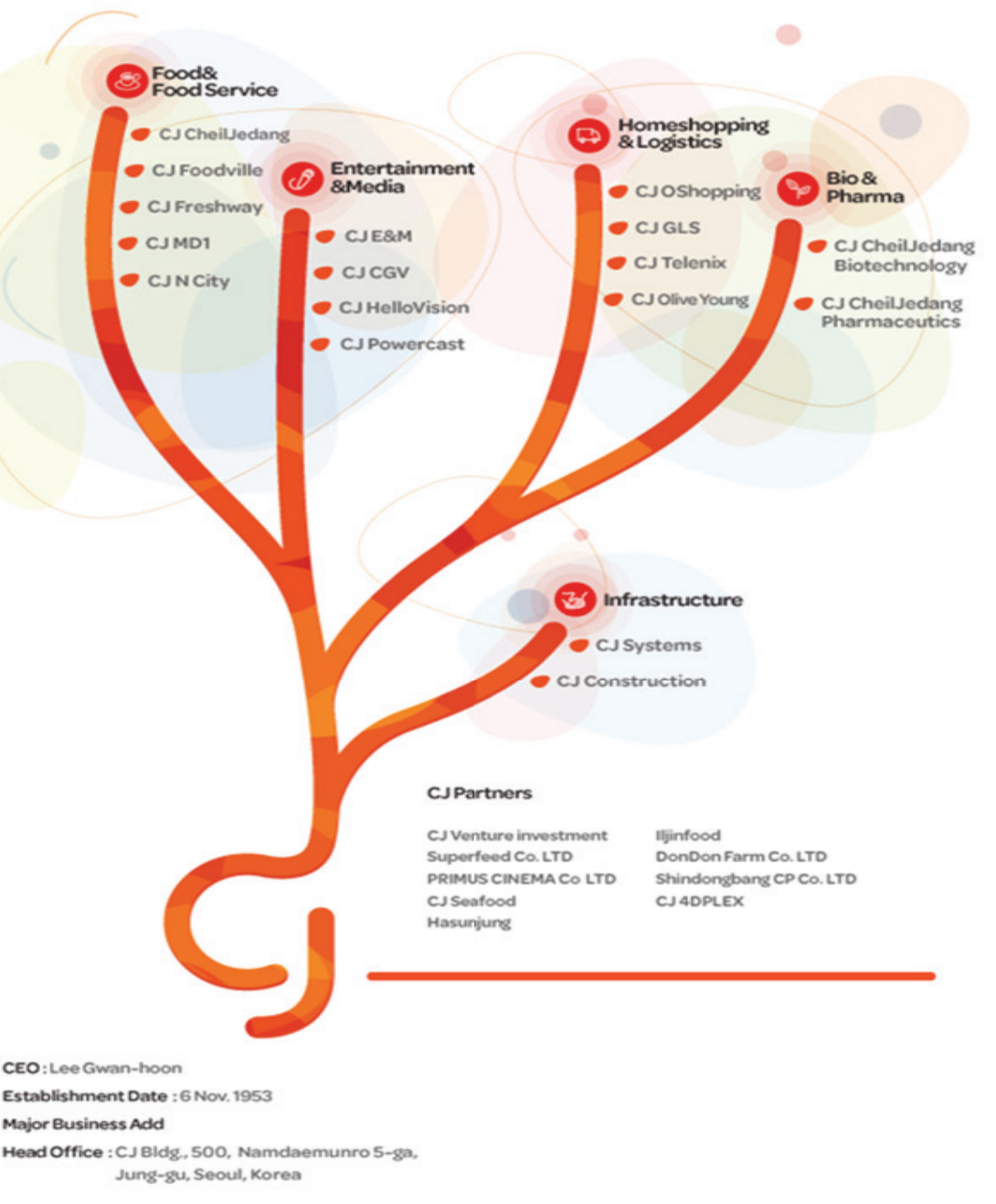

With the conversion into a holding company in 2007.

the $\mathrm{CJ}$ Group has been laying the foundation in becoming

a global company through investment and brand

management of its affiliates.

Focusing on four major businesses such as Food \& Food service, Bio \& Pharma.

Entertainment \& Media, and Home Shopping \& Logistics, CJ has achieved

remarkable results through improved areas of financial management.

planning, business management, human resources management.

Furthermore, CJ will lead the world as a company revolved around

life culture which is more systemic, performance-oriented

and transparent management in line with our vision.

as a global corporation

24 ASIA MARKETING JOURNAL Vol. 15 No. 04 January 2014 
〈Appendix 4〉 Company History (Source: IR data from http://english.cj.net)

\section{Group History}

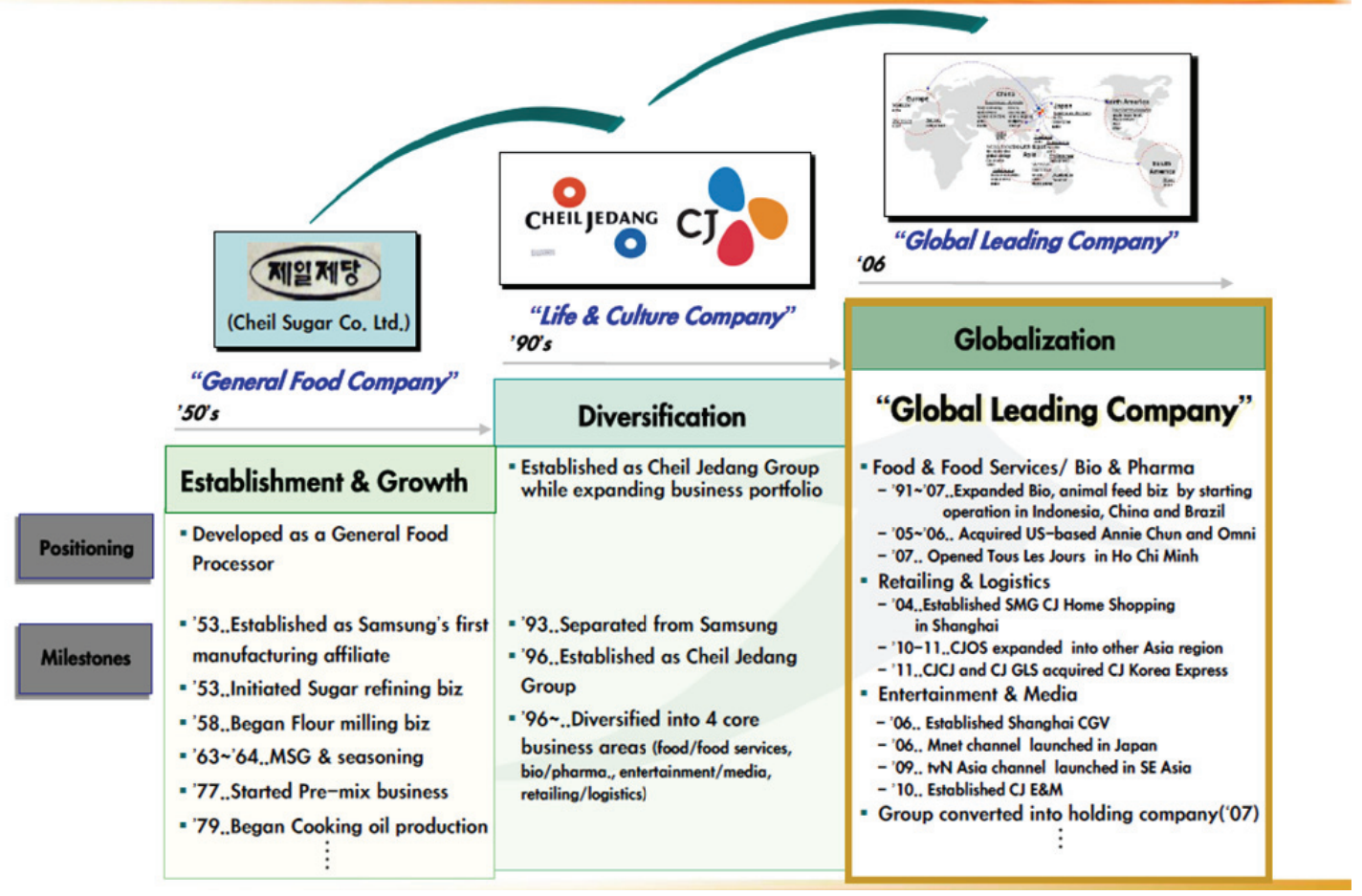


〈Appendix 5〉 CJ Financial Statement (Source: IR data from http://english.cj.net)

\section{Group Overview - Business Overview \& Financials}

\begin{tabular}{|l|} 
Business overview \\
\hline CJ is a well diversified company focusing on four \\
core businesses as below: \\
[ Food \& Food Service] \\
- Expanding global business while maintaining \\
dominant m/s in domestic market: \\
CJ CheilJedang, CJ Freshway, CJ Foodville \\
[Bio \& Pharma] \\
- Strengthening leading position in global Bio \\
market through increasing capacity based on cost \\
leadership : CJ Cheilledang \\
[Entertainment \& Media] \\
- Leading contents provider \& distributor in \\
entertainment and media industry covering movie, \\
music, media, and game sector: \\
CJ E\&M, CJ CGV \\
[Retailing \& Logistics] \\
- Emerging leader in Asian home shopping market \\
with superior presence in domestic market. \\
Logistics business to strengthen as integration \\
process between GLS and KE speeds up: \\
CJ O Shopping, CJ GLS, CJ Korea Express, CJ \\
Olive Young
\end{tabular}

\section{Financial statements}

\begin{tabular}{lcclcc}
\hline B/S & 2010 & 2011 & P/L & 2010 & 2011 \\
\hline Asset & $13,800.6$ & $19,656.1$ & Revenue & $11,615.5$ & $13,271.1$ \\
\hline Liability & $7,789.3$ & $12,092.0$ & $\begin{array}{l}\text { Operating } \\
\text { Profit }\end{array}$ & 833.5 & 907.6 \\
\hline Equity & $6,011.3$ & $7,564.0$ & Net Income & 796.5 & 736.1 \\
\hline $\begin{array}{l}\text { Liability to } \\
\text { Equity Ratio }\end{array}$ & $130 \%$ & $160 \%$ & $\begin{array}{l}\text { OP } \\
\text { Margin }\end{array}$ & $7.2 \%$ & $6.8 \%$ \\
\hline
\end{tabular}

Note: $2010-2011$ in K-IFRS/Consolidated basis

\begin{tabular}{lllll}
\hline (As of end-2011) & Type & No.of shares & Stake & Note \\
\hline Shares & Common & $28,992,063$ & & \\
\cline { 2 - 5 } Outstanding & Preferred & $2,260,223$ & & \\
\cline { 2 - 5 } CJ Corp & Common & $2,971,553$ & $10 \%$ & $\begin{array}{c}\text { Treasury } \\
\text { Shares }\end{array}$ \\
\hline $\begin{array}{l}\text { Major } \\
\text { Shareholder }\end{array}$ & Common & $12,275,574$ & $42 \%$ & \\
\hline
\end{tabular}


〈Appendix 6〉 Product Information "Hatban" (Source: http://english.cj.net)

\section{Always happy life, CJProducts and Services}

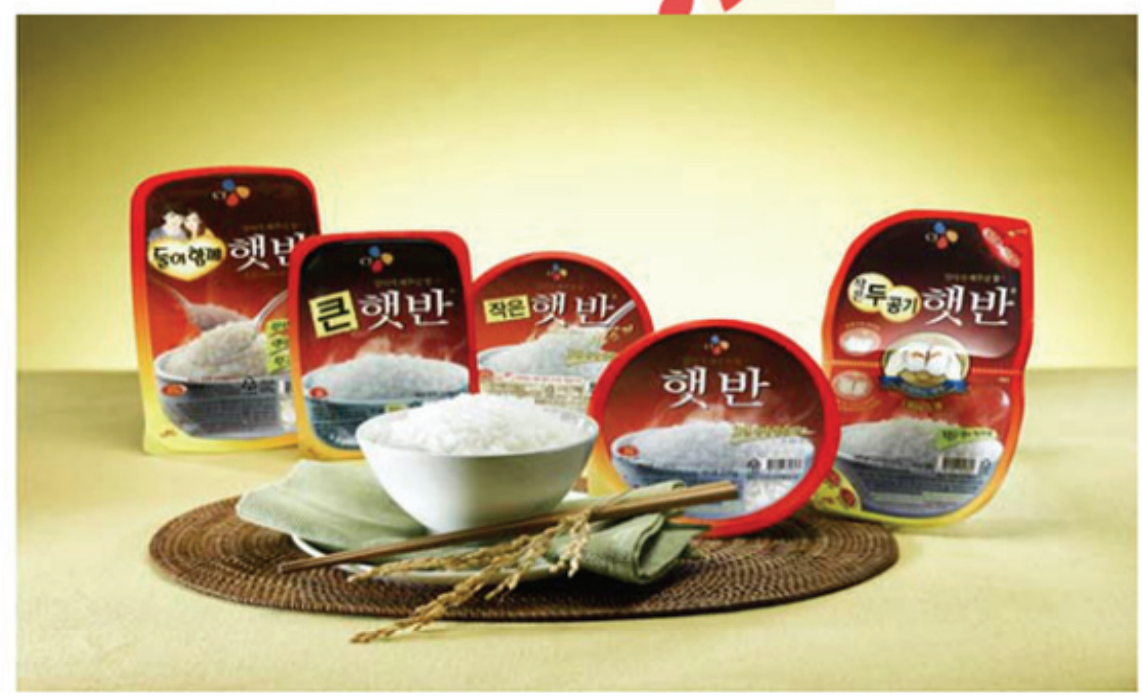

Exo? 3 stita

cj- Cheiljedang

\section{Ready meal}

Hetbahn

CI Hetbahn is microwaveable rice that gives you restaurant quality rice ready in just 2 minutes. The short grain rice is carefully selected and prepared to deliver you all natural nutrient, texture and taste of each grain. CI Hetbahn is free from artificial colour. flavours and preservatives and its shelf life

Toasted Seaweed (Korean toasted seaweed \& Sushi seaweed)

Cl crispy toasted seaweed has unique flavour and fragrance with crunchy texture, It is seasoned with toasted sesame oil and salt and toasted lightly within a toasting process that gives extra crispy texture of seaweed. Each sheet of seaweed has all natural nutrients and its unique flavour.

It usually serves with cooked rice and makes a sushi roll with rice and your favourite ingredients in East Asian cuisine. However, it can be served as ingredients and decorations of many other Asian cuisines also, healthy snack for your family. 
〈Appendix 7〉 Product Information "Lysine" (Source: http://english.cj.net)
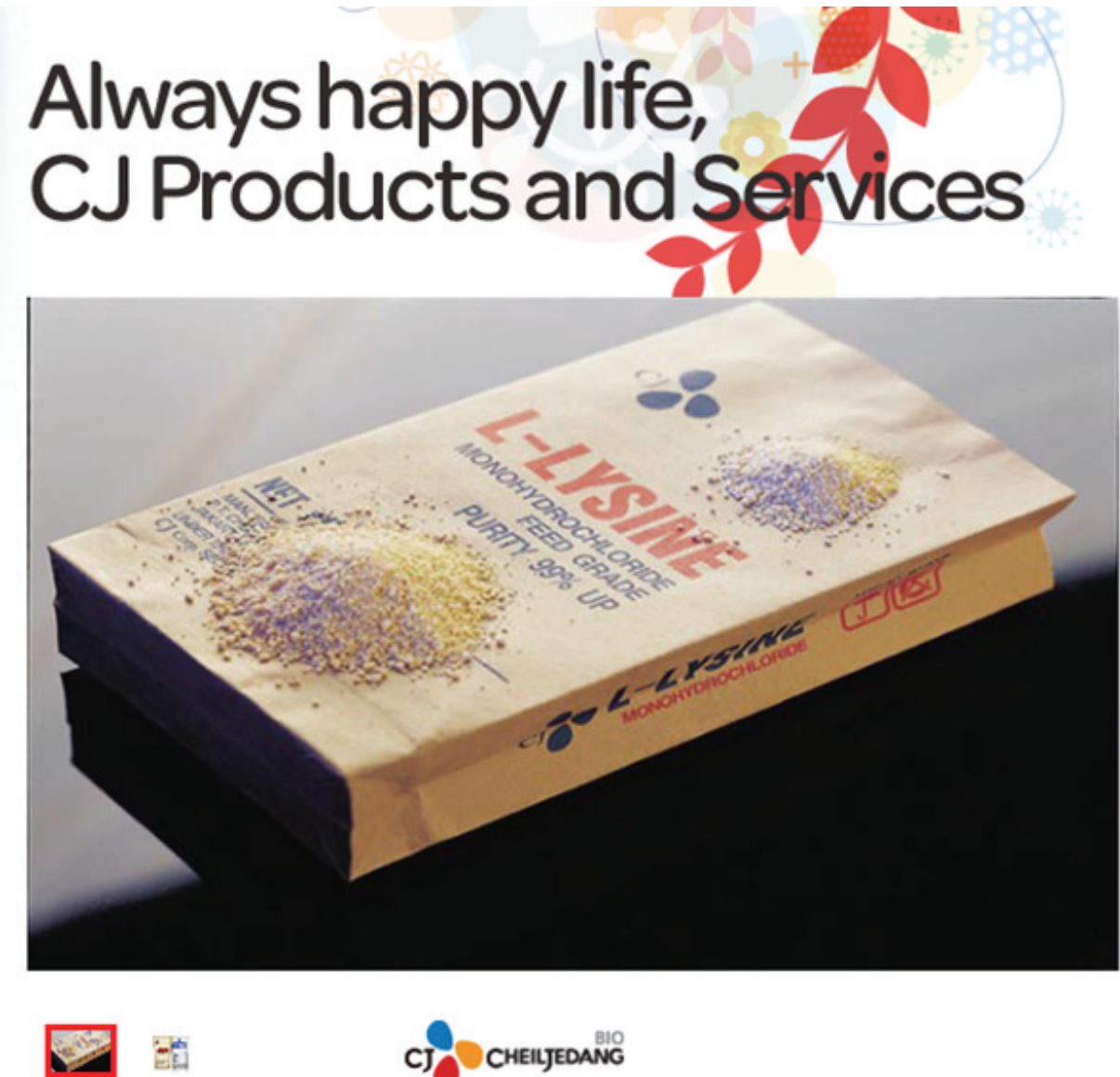

cJOCheIJedang

\section{Lysine}

Lysine is a key nutrient related to the production performance. and considered as the first- or second-limiting amino acid in a typical com-soybean based diet for most species.

Previously, free lysine was regarded as a growth promoter to improve performance, and used as a substitute for protein and lysine sources. However, currently, the use of free lysine is considered as a environment friendly tool to reduce dietary protein levels while maintaining growth performance.

C Bio Lysine is produced by microbial fermentation with natural raw materials which helps to improve performance of animals and to lower user production cost. 
〈Appendix 8〉 Service Information "VIPS" (Source: http://english.cj.net)
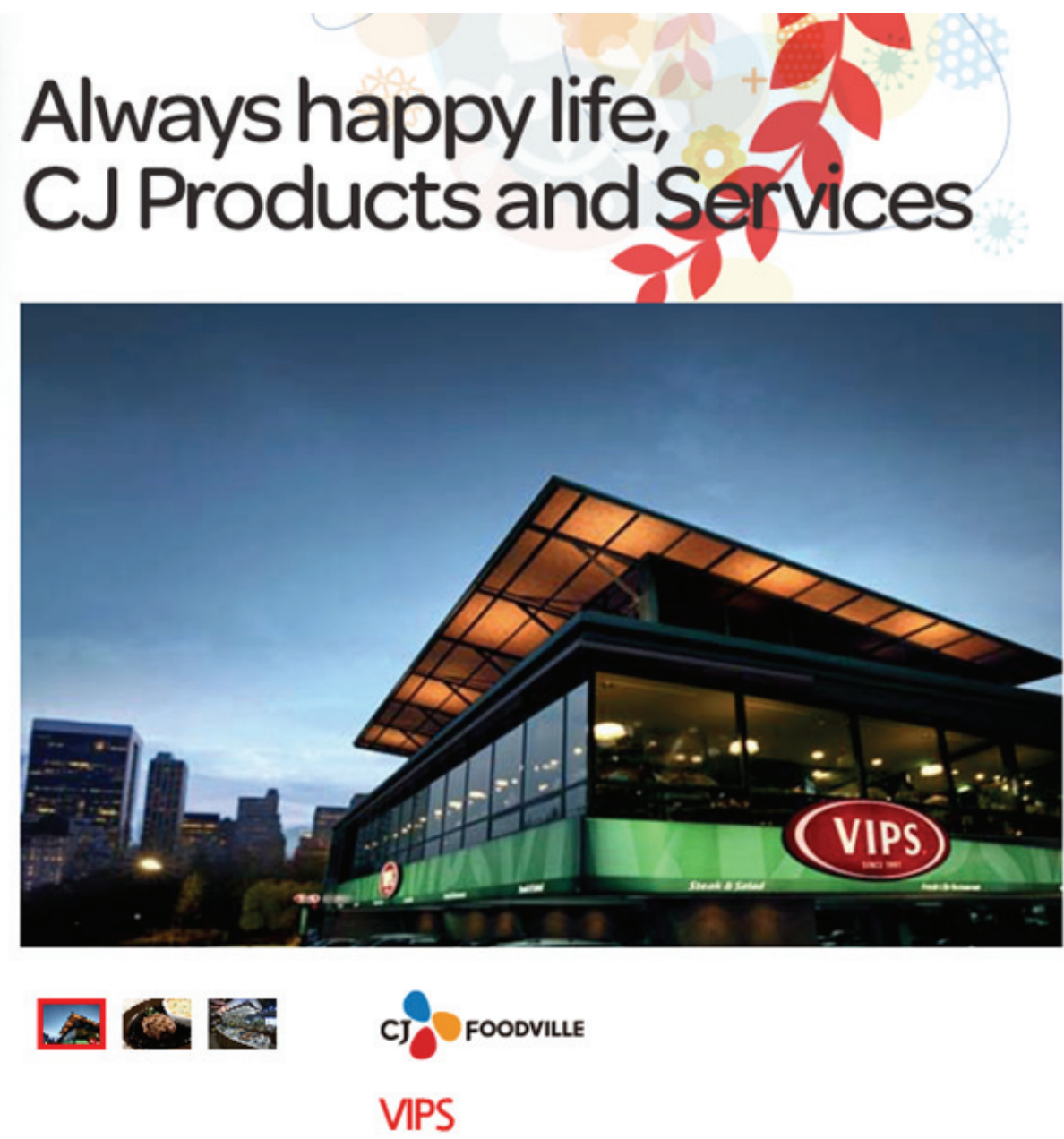

Steak \& Salad Restaurant

VPS, which stands for Very Important Persons Society, means serving every single customer with respect. The first-class Korea family restaurant, UPS, is recognized as the best restaurant from their customers by being ranked top in restaurant in NCSI. VPS offers a variety of healthy dishes to their customers. This is a pleasant and luxurious restaurant where customers can enjoy the best steak made of the finest beef and a salad bar with over 30 choices including fresh salads, high-quality seafood, nice noodles and soup. 
〈Appendix 9〉 Brand Information “CJ GLS” (Source: http://english.cj.net)

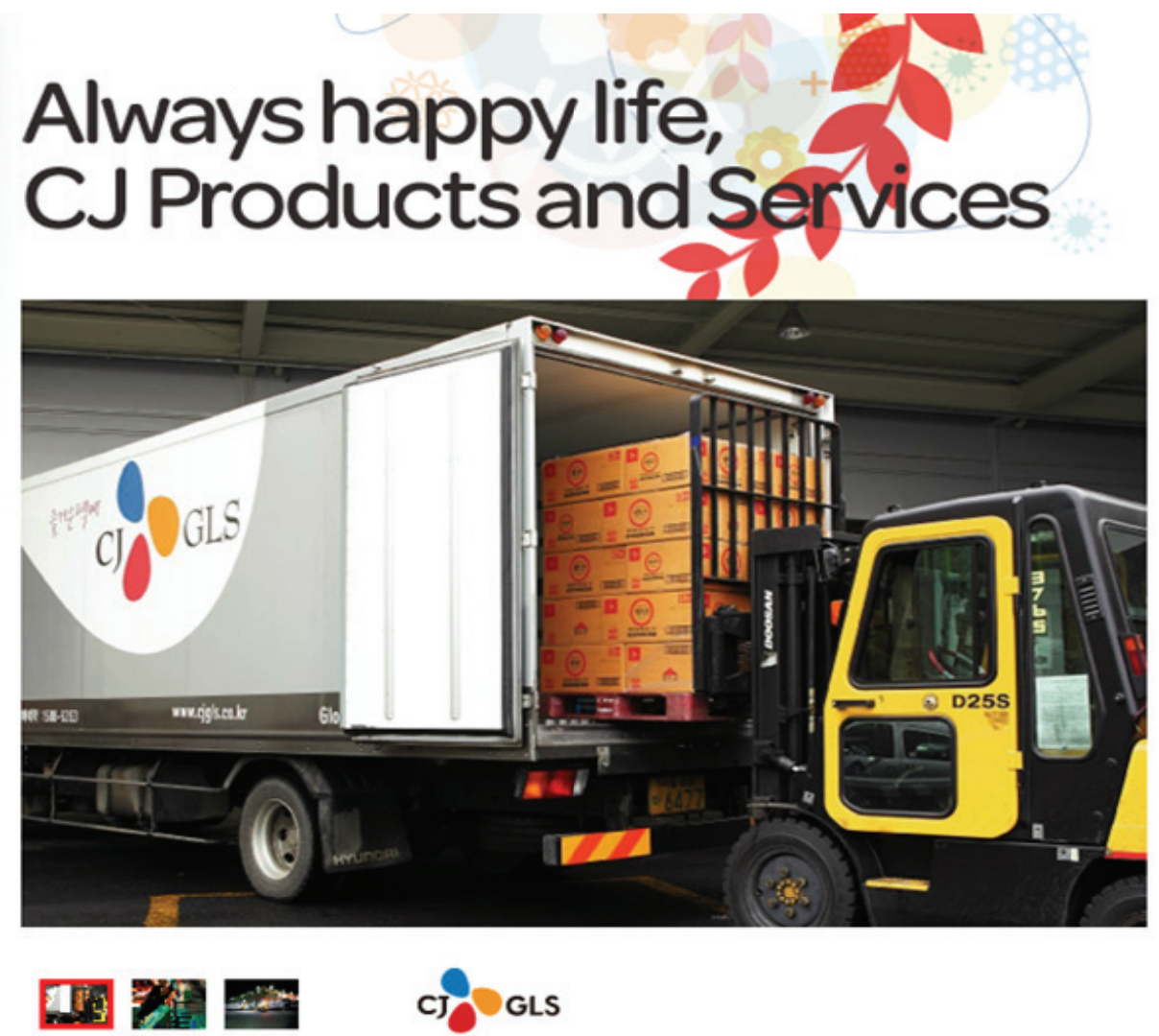

\section{GLOBAL LOGISTICS SERVICE}

Global leading logistics company

C GLS is a global logistics company which provides logistics services through 24 direct networks in 11 countries and has 100 partner companies situated around the world.

It incorporated in China in 2005, acquired Singapore Accord and incorporated CIGLS Asia in 2006. After that, it also incorporated in America and Mexico in 2007 and 2008, respectively. Under these circumstances, it runs the biggest overseas networks including Asia, America and Europe across the nation.

Based on the dedicated manpower in logistics, sophisticated logistic system and accumulated know-how in running logistics, CI GLS has taken the lead in 3PL and delivery services internally and when it comes to global logistic services, it provides total logistics services induding land transport, ocean/air forwarding. customs dearance, storage, etc.

Under the biggest global logistics network and differentiated logistics technologies, C GLS will grow as a global logistic company which represents Asia in 2013. 
〈Appendix 10〉 Service Information "Cine de Chef" (Source: http://english.cj.net)
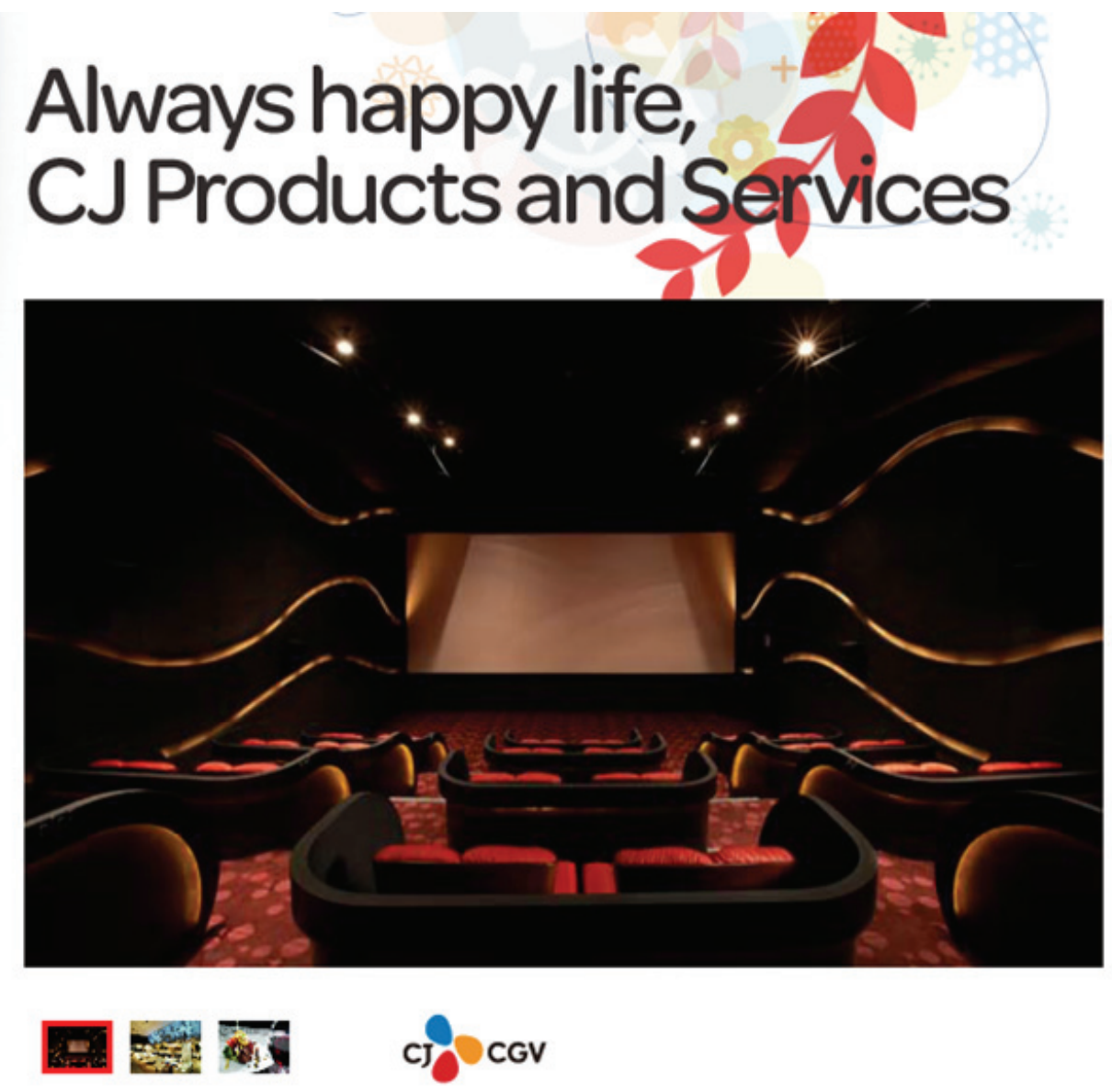

\section{Cine de Chef}

Prestigious Cinema \& Dining

Cine de Chef is a cultural complex presented by CGV which has opened a new chapter in a multiplex in order to touch audiences more deeply. It offers premium services with sensuous healthy food and the best picture and sound system through the innovative attempt of combining the best dining service and the movies. 
〈Appendix 11〉 BiBigo How to Order (Source: http://www.ibibigo.com)

\section{HOW TO ORDER}

1 MENU

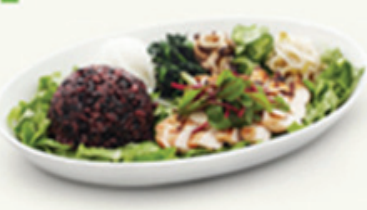

BIBIGO RICE 7,500

Salad type healby bioimbeap

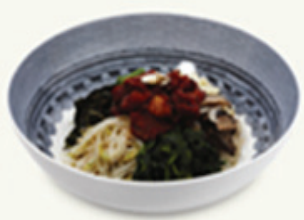

BIBIMBAP 7,500

Trastional biombap wh an array ct nah-mu

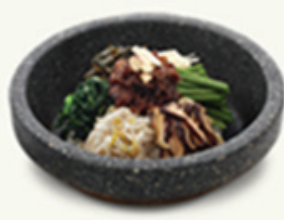

HOT STONE RICE 8,000

Tradtional bbimbap served in sizzing hot stone pot

2 RICE

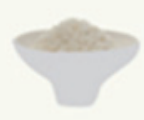

WHITE

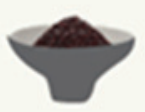

BLACK

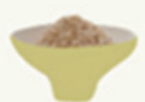

BROWNSWHITE

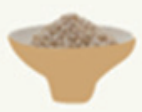

BARLEYWWITE

2. Topping $+1,000$

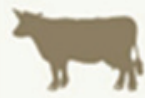

BULGOGI

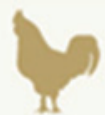

CHICXEN CHICKEN TERIYAKI BREAST

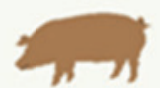

GRILLE SPICY PORK

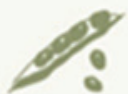

TOFU

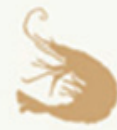

SHRIMP

4 SAUCE

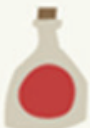

конот

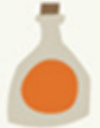

SSAM

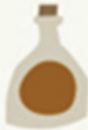

SESAME

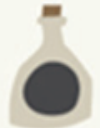

CITRON SOY 